blue-gray with a bright red-brown on the baick.

We watched for a quarter of an hour then all the Hungarian Partridges went between two evergreen trees and huddled together, like chickens, for warmth. One kept walking around hunting for danger. Suddenly they all flew away. What startled them, we don't know.

\section{"The Coyote"}

by Alice Bawron, Anglia, Sask.

Faintly the rising moon,

Etches against the sky

A tawny statue on a hill

His silvery coat

Catching the starlight

As he stands, alone and still.

\section{Kitzman School Nature Hike, March 17}

sent in by Mrs.'Alice J. Wardlaw, Rhein, Sask., as told to her by the pupils.

(Ed. note: only part of the report is given here. The entire report was too long to publish.)

The Grades 1, 2, 3 and teacher went south from the school. We followed the fence walking on the snow drifts. We saw tracks of rabbits, prairie chickens and dogs. They looked like this

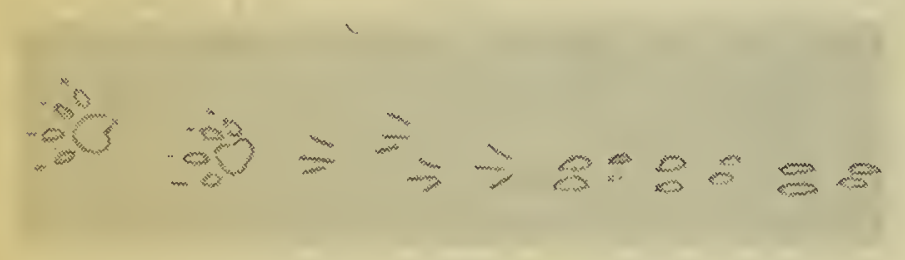

Above the snow we picked up a milkweed or maybe a golden rod stock with a round white ball with a hole in it, where the worm had come out. We carried home a heavy pink and grey rough stone for our museum. The snow banks were three to four feet high, bigger than we were. We went sliding down them and got all wet because the day was warm and the snow was melting. Sometimes our feet broke through and we had fun getting out.

The boys went southeast across a field. Around the bushes wer e grouse or prairie chicken tracks and in the bushes were rabbit runs, little paths made by the rabbits through the bush. In the field were holes where the wild grouse had been sleeping. We saw two bush rabbits. Their ears were brown. Also in the bush we saw a crow's nest and picked rabbit fluff off the trees.

By the side of a slough in the bullrushes were three blackbirds' nests. We took one to take to school but the boy that was carrying it let it fall and left it.

We brought back three stones. One seems to be pink gneiss and one grey gneiss, the larger stone was evidently fire formed because it is smooth hard flinty substance with holes and folds in it.

The girls went north. First we heard a chickadee singing beautifully. Then we saw some big fat pussy willows fully out. In the clumps of shrubs and willows were some branches with brown cones on top. Many branches had a brittle suety black growth on them. One willow branch had a fresh growth under the bark. We took it to school. There was also a round gall on it with several tiny holes in the ball.

Patsy saw two grouse. The first rose off the ground with its tail spread out, the other's tail was not spread. We didn't notice the pattern of the feathers.

A tree with a slit in it had sap running from it. In the undergrowth were many willows upon which the rabbits had been feeding. Under a clump of willows was a rabbit shelter and many rabbit runs through the bush.

In the middle of a big bush we found a decayed tree stump. We broke off a piece and took it with us. It was full of holes. In one hole was a black beetle or bug. It was all numb but when we worried it it moved its legs. Among the things we took back to school were some moss, a hard smooth growth from a tree, a rough grey crinkly substance growing on the bark and a twig with stringy gray-green stuff growing in a bunch on it. The twig was dried and dead.

Under another tree was a pile of small oval shaped balls with feathers in them, grey in colour and about an inch long. Maybe they were owl pellets.

We brought three nests back to school with us for our museum. One was built of fine grass in an up- 